\title{
Quatro visões e a construção de uma história: as interpretações sobre o ressurgimento do movimento operário na região do ABC paulista, 1978-1980
}

\author{
Rafael Leite Ferreira ${ }^{1}$
}

\section{Introdução}

Às 7 horas da manhã do dia 12 de maio de 1978, dezenas de empregados da fábrica Saab-Scania, em São Bernardo do Campo (SP), entraram na empresa, bateram o cartão como diariamente o faziam -, se dirigiram ao local de produção, mas não ligaram as máquinas, ficaram de braços cruzados ao lado delas, em silêncio, sem nada fazer. Nas palavras de Gilson Menezes, na época, operário da Saab-Scania e delegado de base do Sindicato dos Metalúrgicos de São Bernardo do Campo e Diadema:

O pessoal do noturno estava saindo, quando o turno do dia entrou e não ligou as máquinas. Ninguém começou a trabalhar. Não se ouvia o menor barulho na fábrica. [...] Todo mundo marcou o cartão, mas ninguém trabalhou [...]. Às oito horas chegou o gerente geral. Pelo que eu fiquei sabendo, ele olhou, viu que tinha luz, que os cartões estavam marcados, mas que ninguém estava trabalhando. Achou estranho, mas não pensou que era uma paralisação. Não entendeu nada, como também jamais poderia imaginar que ocorreria uma greve. Foi uma surpresa! (MATTOS, 2003, p. 61).

\footnotetext{
${ }^{1}$ Doutorando em História pela Universidade Federal de Pernambuco (UFPE). Integrante do Grupo de Pesquisa "Poder e relações sociais no Norte e Nordeste" (CNPq). Assessor da Comissão Estadual da Memória e Verdade Dom Helder Camara (CEMVDHC)
} 
Dava-se início, assim, ao maior ciclo grevista na história brasileira. Surpreendendo os empresários, o regime civil-militar e, até mesmo, alguns dirigentes sindicais, o desencadeamento das greves em 1978 representou a primeira notícia de grande greve no país após a promulgação do Ato Institucional no5 em 1968 ², ao mesmo tempo em que simbolizou, entre os trabalhadores, a quebra do silêncio de uma década marcada pela falta de liberdade, exploração, arrocho salarial, rotatividade no emprego, intervenção governamental nos sindicatos, despotismo e arbitrariedade patronal no interior das empresas etc.

Três dias após a paralisação na Saab-Scania, a onda grevista atingiu a fábrica da Ford e, no dia seguinte, a Mercedes Benz e a Volkswagen. No dia 18 de maio, chegou à cidade de Santo André e, uma semana depois, a São Paulo, com a paralisação da Toshiba. Em São Paulo, por exemplo, a greve, que começou duas semanas após o início em São Bernardo, chegou a atingir 77 empresas, em quase dois meses de paralisações ${ }^{3}$.

Após a eclosão das greves em 1978, tornaram-se possíveis outras mobilizações, em outras regiões do país, em um processo que se consolidou e se ampliou com as greves dos anos seguintes. Nesse período, foram realizadas inúmeras assembleias e congressos ao longo do território brasileiro; diversas categorias e segmentos de trabalhadores, que jamais haviam experimentado o confronto direto, aderiram às lutas

\footnotetext{
${ }^{2}$ Isto não quer dizer que o período de 1968-1978 tenha sido de letargia entre os trabalhadores brasileiros. Alguns exemplos demonstram indícios de paralisações em algumas empresas durante esse período. Conforme relatou Heloisa de Souza Martins (1979, p. 132), em 1969, o Departamento de Ordem Política e Social (DOPS) foi convocado durante uma paralisação na fábrica Mercedes Benz no ABC paulista; e, em 1974, a polícia prendeu, de uma só vez, 200 trabalhadores da fábrica Volkswagen, situada na mesma região. Entretanto, a notícia destas paralisações não obteve ampla repercussão, dado o bloqueio imposto à imprensa naquela ocasião. Entre 1968-1978, as paralisações foram setoriais e ficaram, portanto, restritas ao interior da empresa.

${ }^{3}$ Uma descrição detalhada a respeito das greves ocorridas em 1978 pode ser vista em Luís Flávio Rainho e Osvaldo Martines Bargas (1983).
} 
grevistas; formou-se uma rede funcional de alianças entre as organizações de base, os movimentos sociais ligados à Igreja - inclusive as Comunidades Eclesiais de Base (CEBs) - e os sindicatos; diversos grupos da oposição - a Ordem dos Advogados do Brasil (OAB), a Conferência Nacional dos Bispos do Brasil (CNBB) e Movimento Democrático Brasileiro (MDB) - passaram a defender os grevistas e a pressionar o governo a devolver os sindicatos aos dirigentes eleitos; e grande parte dos trabalhadores envolvidos nessas greves criou, em 1980, o Partido dos Trabalhadores (PT) e fundou, pouco tempo depois, a Central Única dos Trabalhadores (CUT).

Embora tenha se tornado certo consenso na academia, inclusive entre os trabalhadores e sindicalistas do período, a importância das greves ocorridas na região do $\mathrm{ABC}$ paulista em fins dos anos 70 na luta contra o modelo econômico conservador do regime civil-militar, algumas questões sobre a temática ainda permaneceram divergentes: qual motivo teria levado centenas de operários a cruzarem os braços e decretem greve às empresas? Qual o significado de sua emergência? Em outras palavras, por que se mobilizaram os trabalhadores naquele momento histórico?

Para responder essas questões surgiram, dentro do meio acadêmico brasileiro, quatro tipos de interpretações que, longe de serem unívocas, apresentaram, entre si, posições e orientações, não só diferentes como, às vezes, totalmente opostas uma das outras, tanto em relação às posturas metodológicas e teóricas, bem como às vinculações político-sociológicas sobre o objeto em estudo.

Um primeiro tipo de interpretação argumentou que a retomada da atividade operária e a partir de 1978 foi decorrência, em larga medida, da "superexploração do trabalho" que estava submetida a mão-de-obra na região do ABC paulista. Outra análise partiu do pressuposto que esse movimento foi expressão da "resistência operária" contra o processo de trabalho capitalista. Uma terceira visão considerou que atividade grevista 
deu-se como expressão de uma luta mais ampla por "direitos de cidadania" no interior da sociedade brasileira. E, por último, uma quarta interpretação demonstrou que a "defesa da dignidade" foi o que embasou a luta dos trabalhadores e os levou a combater a miséria e a opressão a que estavam submetidos tanto no interior da fábrica quanto no conjunto da sociedade.

Para a constituição deste artigo, os autores foram selecionados segundo um critério de originalidade, aceitação e críticas recebidas no meio acadêmico. Trata-se de uma seleção que não pretende ser, de forma alguma, a última palavra em relação ao assunto, mas tão somente contribuir para a ampliação do debate. O sumário quadro historiográfico montado a seguir deve ser compreendido, portanto, como uma proposta didática de apontamento dos principais tipos de interpretações existentes a respeito da retomada do movimento grevista no Brasil, no final da década de 1970. No entanto, como em todo quadro, é preciso levar em conta que a simplificação, na maioria das vezes, é inadequada e demasiadamente redutora.

\section{a) A interpretação da "superexploração do trabalho"}

Pela ampla e atual aceitação entre os especialistas em história do movimento operário, dois estudos são os melhores representantes, segundo nosso entendimento, de uma corrente interpretativa pela qual a retomada da atividade operária no $\mathrm{ABC}$ paulista foi decorrência da "superexploração do trabalho" que estavam submetidos os operários das indústrias automobilísticas daquela região: de um lado, temos o estudo do brasilianista John Humphrey que, em 1982, no calor dos acontecimentos, publicou "Fazendo o 'milagre': controle capitalista e luta operária na indústria automobilística brasileira"; de outro, apontamos o sociólogo Ricardo Antunes que, em 1988, publicou “A rebeldia do trabalho: o confronto operário no abc paulista: as greves de 1978/1980".

Brasiliana - Journal for Brazilian Studies. Vol. 2, n.1 (March 2013). ISSN 2245-4373. 
A ideia central da obra de John Humphrey foi, ao analisar seis diferentes aspectos (salários; vantagens não-monetárias; intensidade de trabalho; saúde e segurança; rotatividade da mão-de-obra; disciplina), explicar o ressurgimento do movimento operário brasileiro, no final da década de 1970, procurando apontar os erros e os equívocos das análises de Leôncio Martins Rodrigues e de Maria Hermínia Tavares de Almeida que caracterizaram o operariado das indústrias automobilísticas do $A B C$ paulista como uma "aristocracia operária" em relação ao restante dos trabalhadores brasileiros. Nas palavras de Humphrey: "Até agora, não se encontrou qualquer razão para que os trabalhadores automobilísticos sejam tratados de modo diferente dos outros trabalhadores" (HUMPHREY, 1982, p. 79).

Segundo Humphrey, durante a década de 1970, eram péssimas as condições de trabalho e de salário dos trabalhadores das indústrias automobilísticas no Brasil:

O crescimento da produção, da produtividade e do lucro não impediu que os salários continuassem sob controle, aumentando, algumas vezes, menos que o índice de inflação. $\mathrm{O}$ "sucesso" alcançado pela indústria automobilística foi conseguido à custa dos operários: aumento do dia de trabalho, trabalho intensificado, controle de salários e rotação de mãode-obra (HUMPHREY, 1982, p. 159).

De acordo com John Humphrey, o trabalho pioneiro de Leôncio M. Rodrigues (1970), cuja pesquisa foi realizada no início da década de $1960{ }^{4}$ e as obras de Maria Hermínia T.

\footnotetext{
${ }^{4}$ Nesta obra, o argumento central de Rodrigues foi o de que a passagem, entre os anos 1950/60, de uma massa de trabalhadores da agricultura para a indústria, com a experiência de um emprego em uma empresa multinacional, moderna, localizada na cidade, acabou criando um grupo de trabalhadores que desfrutavam de empregos estáveis e
} 
de Almeida $(1975 ; 1977 ; 1978){ }^{5}$ tenderam a reforçar a noção de que os operários da indústria automobilística do ABC paulista formavam um grupo privilegiado e elitizado no conjunto da classe operária. Para Humphrey, os operários das indústrias automobilísticas do $\mathrm{ABC}$ paulista não exibiam nenhuma marca que os pudessem caracterizar como um setor privilegiado e elitizado, com altos salários, boas condições de trabalho e estabilidade, entre a maioria dos trabalhadores brasileiros. Pelo contrário. Na medida em que, durante a década de 1970, as indústrias automobilísticas do ABC paulista estavam no centro do "milagre econômico", os trabalhadores destas empresas foram mantidos sob um rígido controle do Estado e dos empregadores, disciplinarização, ritmo de trabalho extenuante e intensa produtividade.

Para Humphrey, embora os salários na indústria automobilística fossem relativamente maiores do que a maioria dos trabalhadores brasileiros, isso não dissipou o descontentamento desse segmento de trabalhadores a respeito de seus salários. Havia entre esses operários uma enorme sensação de salário baixo em relação à carga e o ritmo extenuante de trabalho desempenhado: "Os operários da indústria automobilística achavam que precisavam de salários mais altos, que mereciam salários mais altos, e que as firmas poderiam lhes pagar salários mais altos" (HUMPHREY, 1982, p. 86). No que se refere aos benefícios não-monetários, Humphrey destacou que eram constantes as críticas dos trabalhadores em relação ao custo do transporte de ida e volta para as fábricas, à comida servida pelo

de salários altos, melhores condições de trabalho e oportunidades de crescimento em relação à maioria dos trabalhadores brasileiros.

\footnotetext{
${ }^{5}$ A ideia de Maria Hermínia T. de Almeida era de que a "heterogeneidade estrutural da indústria brasileira”, com a coexistência de indústrias "tradicionais" e "modernas", produziu uma diferenciação dentro da classe operária e uma diversidade da atividade sindical, com pautas reivindicatórias diferenciadas entre os trabalhadores desses dois tipos de indústria. Para ela, os operários da indústria automobilística tinham uma situação de emprego específica, mais privilegiada, situação esta que os levava a exigir reformas que não eram do interesse geral da classe trabalhadora brasileira.
}

Brasiliana - Journal for Brazilian Studies. Vol. 2, n.1 (March 2013). ISSN 2245-4373. 
restaurante da fábrica e à assistência médica que era muito cara, bastante inacessível e controlada pela empresa (Ibid., p. 87-88).

No que se refere à intensidade do trabalho, Humphrey ressaltou a extenuante e excessiva carga de trabalho das indústrias automobilísticas. Nas décadas de 1960 e 1970, a maioria das fábricas do $\mathrm{ABC}$ paulista funcionava com uma semana de cinco dias com 48 horas semanais. No período do "milagre econômico", por exemplo, a produção e a carga de trabalho foram aumentadas, sendo bastante comum horário de trabalho acima de 56 horas semanais (Ibid., p. 89-90). Sobre a saúde e a segurança do trabalhador no interior das fábricas automobilísticas, Humphrey percebeu, através de suas entrevistas, inúmeras denúncias dos operários. Entre as reclamações mais comuns estavam o fato de o chão da fábrica estar sempre molhado e escorregadio, as galerias mal sinalizadas, os espaços de trabalho lotados e, em algumas áreas (como funilaria e estamparia), o barulho ser intenso. Estes problemas, segundo Humphrey, combinados com as péssimas condições do ar nas cabines de pintura e de soldagem e nas áreas de tratamento térmico, o intenso barulho na funilaria e a imensa falta de equipamento de segurança eram sinais mais que evidentes das condições ruins e imperfeitas das indústrias automobilísticas para o exercício do trabalho urbano (Ibid., p. 91).

No tocante à rotatividade da mão-de-obra, Humphrey argumentou que a duração média dos empregos nas indústrias automobilísticas era menos de três anos. Para ele, os altos índices de rotatividade indicavam claramente a enorme instabilidade empregatícia desse setor (Ibid., p. 94). Por fim, Humphrey percebeu, a partir das entrevistas realizadas, que a disciplina e a rotinização do trabalho eram aspectos constantes no interior daquelas fábricas (Ibid., p. 99).

De acordo com John Humphrey, foi, portanto, contra tais condições precárias de trabalho e salário, isto é, contra a "superexploração do trabalho", que centenas de 
operários deram início aos protestos na região do $\mathrm{ABC}$ paulista no final dos anos 70 . Como se vê, Humphrey procurou explicar o ressurgimento da atividade grevista no país através da "superexploração do trabalho", criticando ponto a ponto o argumento de Rodrigues e de Almeida de que o operariado da indústria automobilística no $A B C$ paulista se constituía em um segmento privilegiado, elitizado e "apolítico", com interesses voltados apenas para a categoria. Nas palavras de Humphrey:

Estabilidade no emprego, equanimidade na aplicação das regras de trabalho, ambiente saudável etc. não foram encontrados na indústria automobilística do Brasil, na ocasião do estudo. Os níveis de salário flutuavam de acordo com a influência do Estado e dos mercados de trabalho externos; saúde e segurança estavam longe de ser ideais; o emprego era instável para muitos grupos de trabalhadores; a produtividade estava sempre sendo aumentada sem técnicas melhores; e o grupo supervisor exercia um grande poder, muitas vezes de modo arbitrário. Esse exame das condições de trabalho basta para justificar a rejeição de teorias que sustentam que os operários da indústria automobilística estão satisfeitos com a sua situação (Ibid., p. 103).

Outro autor que também compartilhou da noção de "superexploração do trabalho" para explicar o ressurgimento do movimento operário e sindical no $\mathrm{ABC}$ paulista a partir de 1978 foi o sociólogo Ricardo Antunes. Para ele, o "elemento impulsionador" para o ressurgimento do movimento operário brasileiro foi a denúncia e a luta dos trabalhadores contra a política econômica do regime civil-militar a qual era mantida 
pela "superexploração do trabalho", na simbiose extenuante e intensificada das formas absoluta e relativa de extração do sobretrabalho. Ou seja, para Antunes, o "principal motor" para a ação do operariado:

Foi a luta contra a superexploração do trabalho, contra o "arrocho salarial", conforme denominação dada pelos trabalhadores à compressão salarial a que estavam submetidos pela política econômica do pós-64 e que atingia indiscriminadamente o conjunto do proletariado (ANTUNES, 1988, p. 158).

Ricardo Antunes utilizou a noção "superexploração do trabalho" para enfatizar e precisar a maneira pela qual a indústria automobilística no Brasil utilizou-se tanto do prolongamento da jornada de trabalho quanto da intensificação do trabalho como formas de extração da mais-valia.

Partindo de uma perspectiva marxista para analisar o movimento paredista, Antunes considerou o aspecto "econômico" como o eixo central das reivindicações e das lutas do operariado paulista durante o final da década de 1970. Segundo ele:

Outra não pode ser a conclusão quando se estuda a pauta de reivindicações dos metalúrgicos; a luta por um índice que contemplasse um efetivo ganho de produtividade além do INPC, um piso salarial aceitável, a estabilidade como contraposição à rotatividade da força de trabalho, bem como a reivindicação pela redução da jornada de trabalho, constituíam-se no leque principal 
de reivindicações cujo eixo visava questionar a intensidade da exploração do trabalho, combater o arrocho salarial, o despotismo e a opressão fabril (Ibid., p. 83).

De acordo com Antunes, por mais que as outras reivindicações (luta contra o intervencionismo estatal e pela democratização, autonomia e liberdade sindical, direito de greve, maior organização no espaço fabril, pela negociação direta, pela contratação coletiva) tivessem sido elementos importantes na luta dos trabalhadores, elas estavam em um segundo plano, pois o aspecto "econômico", ou seja, o "financeiro" era o que estava, de fato, no primeiro plano de reivindicações dos trabalhadores. Em suas palavras: "Ainda que outras importantes reivindicações estivessem presentes nas greves, não se pode deixar de assinalar, sob o risco de perda do elemento fundante, que o eixo das Greves definiase contra a superexploração do trabalho, contra o arrocho salarial" (Ibid., p. 27).

Segundo Antunes, após o golpe civil-militar de 1964, especialmente durante a década de 1970, o governo brasileiro implantou um conjunto de medidas econômicas que promoveu uma intensa "superexploração do trabalho" - a fórmula ideal encontrada pelos militares para cortar despesas e aumentar os lucros dentro de uma conjuntura nacional e internacionalmente recessiva. Entre tais medidas, Antunes citou a determinação dos reajustes salariais, exclusivamente, através de decretos governamentais; o rebaixamento dos salários; a piora nas condições de trabalho; a dilapidação das energias físicas e psíquicas dos trabalhadores; o aumento da subordinação do trabalhador à disciplina da empresa; o maior controle das greves; o aumento de produtividade nas empresas e de rotatividade no emprego; as intervenções nos sindicatos, incluindo expurgos, espionagem, prisões, torturas, campanhas de 
difamação, perseguições arbitrárias, censura e assassinatos de inúmeros sindicalistas etc. Como destacou Antunes:

Ao contrário de condições e relações de trabalho favoráveis, o mundo do trabalho [no ABC paulista durante o final da década de 1970] vivenciava uma realidade despótica e opressiva, um ritmo extenuante de trabalho, controlado pelo cronômetro taylorista e pela produção em série fordista, além de uma jornada de trabalho prolongada, pelo mecanismo das horas extras e pelos turnos de trabalho (Ibid., p. 164).

Como se pode ver, seguindo a mesma perspectiva de John Humphrey, para Ricardo Antunes foi contra todas as precariedades das condições de salário e trabalho citadas no parágrafo anterior, isto é, tendo como causalidade fundante a "superexploração do trabalho", que se deu o início das greves no ABC paulista no final da década de 1970. Conforme salientou: "[...] a luta tinha seu eixo central no combate à superexploração do trabalho, priorizado no combate ao arrocho salarial" (Ibid., p. 159).

\section{b) A interpretação da "estratégia da recusa"}

Uma segunda interpretação para o ressurgimento do movimento operário no Brasil foi feita por Amnéris Angela Maroni através do livro "A estratégia da recusa: análise das greves de maio/78", de 1982. Para esta autora, a mobilização dos trabalhadores naquele momento histórico foi, na verdade, uma expressão da "resistência operária contra o processo de trabalho capitalista". Ou seja, foi uma prática invisível de resistência levada a 
cabo no interior das empresas voltada, em grande parte, para o "questionamento à organização capitalista do processo de trabalho".

Segundo o estudo de Maroni, o questionamento da racionalidade capitalista, do poder do capital na organização fabril, constituiu-se no eixo central da luta grevista. Para ela, o arrocho salarial, a falta de liberdade sindical etc., constituíram-se em elementos, sem dúvida, importantes para o desencadeamento do conflito, mas que não davam conta de sua emergência particular (Ibid., p. 3). Era necessário, assim, segundo seu entendimento, buscar apreender a "face oculta" da luta através de seus aspectos não explícitos.

De acordo com Maroni, a grande maioria das obras sobre a história do movimento operário no Brasil se restringia à problemática organizacional, partidária, sindical. Para ela, nessas análises, o "cotidiano operário", ou seja, "o vivido na fábrica" não tinha nenhum espaço. Na introdução do livro, a autora afirma que seu objetivo seria fugir de tais perspectivas e tomar como objeto de investigação as diversas formas de opressão e de resistência vividas no cotidiano das fábricas do ABC paulista.

De acordo Maroni, as já mencionadas obras de Leôncio Rodrigues (1970) e de Maria Hermínia T. de Almeida $(1975 ; 1977 ; 1978)$ encarregaram-se de elaborar alguns "mitos" a respeito dos trabalhadores empregados nas indústrias automobilísticas do ABC paulista, em especial, o mito de que a "satisfação" dos trabalhadores deste setor negava-lhes a possibilidade de qualquer questionamento ao "processo de trabalho capitalista". Em outras palavras, devido à boa condição de seus empregos, esses operários negavam a possibilidade de qualquer tipo de revolta contra o sistema capitalista. Para Maroni, tanto as ideias de Rodrigues quanto as de Almeida reforçaram a noção de passividade do trabalhador ao processo de trabalho capitalista: 
Para L. M. Rodrigues, as condições particulares da emergência da "indústria moderna" foram imputadas como obstáculos a uma "consciência anticapitalista"; para M. H. Tavares de Almeida, abre-se com elas a possibilidade de um sindicalismo combativo, porém circunscrita a conflitos específicos, que não colocam em xeque o sistema. Em uma ou outra análise a consciência do trabalhador não emergiria (MARONI, 1982, p. 56-57).

Segundo Amnéris Maroni, diferentemente das ideias imobilistas de Rodrigues e de Almeida, em determinados momentos e situações, os trabalhadores tornam-se sujeitos históricos ativos e lutam contra o poder do capital. Para ela, a eclosão das greves na região do ABC paulista em 1978 era um claro exemplo de contestação dos trabalhadores à ordem vigente e que, portanto, desmentia a tese pacífica do trabalhador brasileiro ante ao "processo de trabalho capitalista". Em suas palavras: "[...] já não se aposta na capacidade de integração da classe trabalhadora via organização do processo de trabalho. Ao contrário, esta última, enquanto tal é alvo de questionamento" (Ibid., p. 59).

Para Maroni, foi como uma recusa à lógica de organização do trabalho capitalista nas indústrias automobilísticas (controle do tempo, do espaço e da produção, aplicação de sanções normalizadoras etc.) que centenas de operários cruzaram os braços na região do $A B C$ paulista e decretaram greve às empresas no final da década de 1970. Segundo a autora, a paralisação foi a forma encontrada pelos trabalhadores para questionar a estratégia do capital que buscava, através da organização e/ou reorganização do processo de trabalho, deixar-lhes inertes, sujeitos às ordens da hierarquia da fábrica e retira-lhes o controle sobre o processo de produção. Como salientou a autora: "As formas de resistências ao trabalho traziam à tona, para os trabalhadores, a possibilidade ou a ideia de 
algum controle sobre o processo de trabalho [...]. [Com a greve] Ainda que por um breve espaço de tempo, parte da estrutura de poder do capital desagrega-se; seu domínio, momentaneamente, ofusca-se" (Ibid., p. 63; 101).

É importante ressaltar que para Amnéris Maroni, o ressurgimento da atividade grevista na região do ABC paulista em fins da década de 1970 não foi consequência de uma consciência "anticapitalista" e "revolucionária" do proletariado, tampouco emergiu, no decorrer do movimento, uma "consciência socialista" entre a classe. "Ao lutar por aumento salarial, melhores condições de trabalho [...], os grevistas, em maio de 78, viram-se obrigados a lutar também contra alguns aspectos da organização capitalista do processo de trabalho[...]", mas não o sistema capitalista como um todo (Ibid., p. 194). A greve foi, na verdade, de acordo com Maroni, o momento pelo qual os operários procuraram se contrapor à dura "vigilância" e o acirrado "controle" no interior das fábricas automobilísticas e lutaram pela possibilidade de impor algum controle no ritmo de trabalho.

\section{c) A interpretação da "luta pela cidadania"}

Em meio ainda aos acontecimentos do período, o cientista político José Álvaro Moisés publicou, em 1982, o livro "Lições de liberdade e de opressão: os trabalhadores e a política", lançando uma nova visão para o ressurgimento do movimento operário no final da década de 1970. De acordo com o autor, seu objetivo era apreender o real significado daquelas greves, fugindo das interpretações "economicistas", especialmente as de John Humphrey. Segundo Moisés, as paralisações deveriam ser vistas no "terreno da luta por direitos sociais e políticos" (MOISÉS, 1982). Para ele, fora desse terreno, correrse-ia o risco de tratar o surgimento das lutas operárias no $\mathrm{ABC}$ paulista apenas como 
mais um movimento na história de luta dos trabalhadores. "Não ver isso é não entender o fenômeno do $A B C^{\prime \prime}$ (Ibid., p. 149).

Moisés viu naquele evento um momento único na história do movimento operário. Por isso, fez questão de destacar a singularidade daquelas greves. Para ele, pela primeira vez, os trabalhadores estavam lutando pelo "direito de lutar" no interior da sociedade, isto é, lutando para estarem no centro da vida política do país, imprimindo suas marcas nas regras do jogo político que estavam sendo gestadas no Brasil naquele momento histórico. “Os operários chamaram a atenção da sociedade para o fato de que se recusam a permanecer na condição de 'cidadãos de segunda classe'"' (Ibid., p. 19).

De acordo com Moisés, aquelas greves representavam uma clara e inequívoca vontade de os operários entrarem pela porta da "abertura política", não para simplesmente aceitá-la, mas para ampliá-la e para imprimirem nela a sua marca e os seus interesses. Em suas palavras:

Os trabalhadores voltaram ao centro da vida política do país, mas, contrastando com o passado, não querem apenas participar nas condições que são impostas, de fora para dentro. Voltaram imbuídos de vontade de imprimir a sua marca à luta pela democracia que se desenha no país. Querem a democracia, mas também querem dizer qual é a democracia que entendem ser necessária ao país (Ibid., p. 16).

Para o autor, o grande embate dos trabalhadores não se deu no campo econômico, mas no político. Segundo ele, a luta pelas questões salariais não era o primeiro objetivo da atividade grevista, mas sim a luta por uma "cidadania plena" que, para ser efetiva, teria 
de garantir os "direitos sociais e políticos básicos", como o direito de greve, o direito de livre organização sindical e política e a completa autonomia frente ao Estado.

Segundo Moisés, na ótica de muitos operários, estava o fato de que não adiantava simplesmente lutar por melhores salários se eles seguiam correndo o risco de perderem o emprego a qualquer momento. Era necessário, portanto, como primeiro objetivo, garantir o "direito de lutar". A esta questão, Moisés argumentou:

Os direitos sociais aparecem como condição de possibilidade dos direitos políticos, da mesma forma que as conquistas políticas são percebidas como condição da conquista social. As experiências dos anos recentes têm demonstrado aos trabalhadores que se eles desejam melhores salários é preciso garantir essa possibilidade, lutando pelo direito de greve. Como este direito é negado por um regime despótico e excludente, os trabalhadores, ao lutarem por melhores condições de vida, acabam por se converter nos novos artífices da luta pela democracia no Brasil (Ibid., p. 183).

De acordo com Moisés, os metalúrgicos do $\mathrm{ABC}$, ao colocarem no centro das suas reivindicações a luta pelo próprio "direito de lutar", transcenderam seus interesses mais específicos e tocaram no que era a "pedra de toque" de toda a questão do período: a conquista dos direitos de cidadania para a sociedade brasileira. Em suas palavras: "[...] os metalúrgicos do $A B C$ transcenderam o terreno estrito das funções sindicais e, mesmo, os seus interesses mais imediatos, colocando na ordem do dia a reivindicação de direitos sociais e políticos que abraçam um conjunto bastante mais amplo das classes populares brasileiras" (Ibid., p. 174). 
Como se pode perceber, Moisés, ao pretender realizar uma "análise política" da ação do operariado metalúrgico, acabou por desenvolver a interpretação pela qual o "principal motor" para o desencadeamento do movimento foi a própria busca dos trabalhadores pelo "direito de lutar" no interior da sociedade. Ou seja, os operários lutaram pelo direito de não ficarem em "silêncio" em meio ao caos, o direito de poder "botar o bloco na rua", o direito de poder participar mais significativamente das novas regras do jogo político que estavam sendo gestadas no país. Para o autor, o aspecto mais importante das greves daquele período não foi as conquistas específicas e imediatas da classe trabalhadora, mas sim o significado que teve no impulso e na participação da luta pela democracia no país. Como ele próprio argumentou, era "[...] no terreno dos efeitos sociais e políticos sobre o conjunto da sociedade que convinha ir buscar o significado mais geral da eclosão das greves do $A B C$ paulista" (Ibid., p. 171). Assim, definindo-se como um movimento pela conquista de direitos sociais e políticos dos trabalhadores, o ressurgimento da atividade grevista qualificou-se como ato extremamente decisivo na luta pela democracia política do país.

As palavras a seguir resumem, grosso modo, a ideia central da obra de Moisés:

No futuro, talvez a greve dos metalúrgicos do $\mathrm{ABC}$ fique conhecida, na história brasileira, como o episódio que abriu o moderno processo de conquista de direitos fundamentais de cidadania para os trabalhadores. Pois é certo que, para as grandes massas de trabalhadores brasileiros, a greve serviu para tornar mais claro o sentido atual da luta do povo: o novo nome da democracia no Brasil é direito de greve e direito de lutar por condições mais dignas de existência (Ibid., p. 154-155). 
Seguindo a mesma interpretação "política" de Moisés, Iram Jácome Rodrigues defendeu, em seu livro, "Sindicalismo e política: a trajetória da CUT", de 1997, que o ressurgimento do movimento operário deu-se basicamente "[...] como expressão de uma luta mais ampla por direitos de cidadania no interior da sociedade" (RODRIGUES, I., 1997, p. 19). Ou seja, para ele, os conflitos ocorridos na região do $A B C$ paulista no final da década de 1970 estiveram intimamente associados à "luta por direitos democráticos" no conjunto da sociedade, mais precisamente, por "direitos de cidadania".

De acordo com Iram Rodrigues, as diversas interpretações existentes na historiografia brasileira a respeito das greves daquele período foram de inegável importância acadêmica pelo fato de os cientistas sociais buscarem entender os "novos" movimentos populares, isto é, as diversas experiências de luta dos "de baixo". Entretanto, diversas destas interpretações, especialmente, aquelas de teor "economicistas", dispunham de uma significativa limitação pelo fato de descartarem o aspecto "político" existente na luta dos trabalhadores ${ }^{6}$. Para o autor, as interpretações que privilegiavam a pauta econômica/salarial estavam presas à "esfera da produção", ao espaço interno da fábrica, "o lócus do despotismo do capital", em vez de estarem relacionadas "[...] às instituições do país, ao lugar dos trabalhadores no interior dessas instituições, captado pela noção de cidadania política" (Ibid., p. 20). Segundo Iram Rodrigues, os autores "economicistas":

\footnotetext{
${ }^{6}$ É importante destacar que Iram Rodrigues considerou limitada não apenas as interpretações economicistas, especialmente de Humphrey e de Antunes, mas também a ideia de "dignidade" formulada por Laís Abramo, como se verá mais adiante. Para ele, essas visões eram limitadas por terem negligenciado a "dimensão política" das greves (Ibid., p. 23).
} 
[...] com suas reflexões diferenciadas sobre o porquê do movimento grevista no final dos anos 70, nos ajudam a entender, em parte, o fenômeno da luta dos trabalhadores. No entanto, há outros aspectos da emergência operária e sindical que deveriam ser melhor explorados para se apreender, nas suas especificidades, os problemas que se colocam hoje para a atuação da classe trabalhadora e do sindicalismo no país (Ibid., p. 19).

Nesse contexto, contrapondo-se a esses tipos de interpretação, Iram Rodrigues enfatizou em sua obra que, muito embora a questão mais visível no movimento grevista tenha sido o combate por melhores condições de salário trabalho, o conflito no $\mathrm{ABC}$ paulista deu-se, juntamente no fluxo dos demais movimentos sociais do período, como expressão de uma luta mais ampla por "direitos de cidadania" no interior da sociedade.

Para Iram Rodrigues, havia na fala daqueles operários muito mais que uma simples reivindicação salarial ou uma sensação de "dignidade violentada" (como fora vista por Laís Abramo), havia uma luta mais ampla por direitos, ou seja, um embate que era maior do que o próprio local de trabalho. Em outras palavras, havia uma luta que era, na verdade, uma luta por direitos de moradia, de educação, de saúde, de saneamento básico do bairro, de eleições diretas e de justiça social. Neste sentido, a atividade grevista daquele período expressou "[...] o alto grau de insatisfação de amplas parcelas de trabalhadores que não aceitavam mais uma cidadania limitada e queriam participar mais ativamente da vida nacional" (Ibid., p. 30-31).

Segundo Iram Rodrigues, havia, de fato, um aspecto "político" nas greves do $\mathrm{ABC}$ paulista pelo fato de os trabalhadores, através das críticas à política econômica do governo e da luta contra os baixos salários, do direito de greve, da defesa da negociação 
direta com o patronato e da liberdade sindical, trazerem para a esfera pública amplas parcelas da sociedade que até então não tinham entrado para a luta política. Para o autor, as greves operárias fizeram emergir inúmeros focos de oposição ao regime civilmilitar em diversos setores da sociedade brasileira (Ibid., p. 29). Em suas palavras:

O sindicalismo transformou-se em protagonista das demandas políticas e sociais de parcelas significativas das classes trabalhadoras, tanto em São Paulo quanto em todo o Brasil, trazendo para a esfera pública amplos contingentes que até então não tinham maior participação no processo político. Seu impacto na sociedade foi de tal magnitude que possibilitou a criação de um partido, o Partido dos Trabalhadores, que procura defender, no âmbito da política, os interesses mais gerais dos trabalhadores (Ibid., p. 16-17).

Ao longo de sua obra, Iram Rodrigues utilizou o surgimento do PT, em 1981, da CUT, em 1983, e do fato de o líder sindical Luiz Inácio da Silva (o Lula) concorrer às eleições presidenciais de 1989, como exemplos para demonstrar que o ressurgimento da atividade grevista no final da década de 70 não representou simplesmente demandas salariais, mas expressou uma luta por se fazer ouvir na sociedade brasileira, isto é, expressou a luta por "direitos de cidadania".

\section{d) A interpretação da "defesa da dignidade"}

Fruto de sua dissertação de Mestrado na Universidade de São Paulo (USP) em 1986, o livro de Laís Wendel Abramo “O resgate da dignidade: greve metalúrgica e 
subjetividade operária" trouxe à tona um quarto tipo de interpretação para o ressurgimento do movimento operário no Brasil. Segundo a autora, a "defesa da dignidade" 7 foi o elemento principal que desencadeou a ação grevista no ABC paulista. Nesta ótica, as greves ocorridas no período representaram, portanto, uma reação à situação de "dignidade violentada" vivenciada pela classe trabalhadora ao longo das décadas de 1960 e 1970. Isto é, as greves ocorreram como uma forma de resistência e de combate ao "sofrimento moral" vivido pelo trabalhador brasileiro durante o projeto econômico conservador da ditadura civil-militar.

Laís Abramo baseou o seu estudo na obra da filósofa francesa Simone Weil (1979), cujo depoimento sobre sua vivência em uma fábrica metalúrgica, na França da década de 1930, alertou sobre o fato de muitos fatores importantes numa greve não poderem ser simplesmente enquadrados em "indicadores objetivos", isto é, em reivindicações salariais. Ao descrever sobre a situação do operariado francês no período, Weil chamou atenção para o "sofrimento moral" provocado pelo trabalho realizado naquelas condições e a possibilidade deste fator subjetivo desencadear uma greve ou de estar presente na pauta de reivindicação dos operários.

Neste sentido, tomando como base a argumentação de Weil, Abramo constatou a existência de um profundo sentimento de "injustiça, exclusão e humilhação" entre os operários do ABC paulista ao longo da década de 1970 e que o ressurgimento das lutas operárias nessa região a partir de 1978 teve, portanto, um caráter de "recuperar a dignidade" muito maior do que a própria demanda salarial do momento. Na fala de um

\footnotetext{
7 De acordo com Laís Abramo, na fala dos trabalhadores, a expressão "dignidade" era direito, respeito e merecimento. Isto é, era poder andar de cabeça erguida; era sentir-se novamente gente e parte de uma categoria, representada por um sindicato que conseguia impor limites à situação de opressão; era algo que estava sendo negado (nas condições de trabalho e na conjuntura política vigente), e algo que só poderia ser recuperado por meio da luta, do confronto, da ação coletiva, ou seja, por meio das greves. Nisso, para a autora, estaria o "resgate da dignidade" (ABRAMO, 1999, p. 273-275).
}

Brasiliana - Journal for Brazilian Studies. Vol. 2, n.1 (March 2013). ISSN 2245-4373. 
grevista entrevistado por Abramo: "A greve estava mais pela honra do cara do que pelo aumento" (ABRAMO, 1999, p. 42).

Para Laís Abramo, entre as décadas de 1960 e 1970, o ABC paulista sofreu um intenso processo de modernização e de crescimento econômico, oriundo, principalmente, da instalação das indústrias automobilísticas na região. Entretanto, apesar do "milagre" econômico vivido pelo país entre os anos de 1968-1974, os metalúrgicos do $\mathrm{ABC}$ paulista não colheram os frutos de tal crescimento. Essa nãoparticipação nos lucros da empresa gerou, de acordo com Abramo, uma forte "sensação de injustiça" ante o trabalho. "[...] os trabalhadores experimentavam uma sensação de injustiça que tinha na sua base a consciência da importância do valor por eles produzido para o crescimento das empresas" (Ibid., p. 59). Isto é, segundo a autora, havia uma profunda e infeliz percepção entre os trabalhadores de que existiam consumos que não estavam sendo adquiridos e necessidades que não estavam sendo atendidas (Ibid., p. 59-60).

Para Abramo, acompanhado a esse sentimento de injustiça, veio também a noção de "perda" e de "frustração". Em relação ao primeiro sentimento é importante destacar que havia entre os operários a sensação de que eles não estavam recebendo aquilo que mereciam (o que lhes era devido) em troca do valor do seu trabalho (Ibid., p. 142). No que se refere ao sentimento de "frustração", a autora salientou:

Os trabalhadores sentiam-se como "um autômato programado", sentiam a sua vida toda cronometrada, ou "perdendo-se" em um trabalho desgastante e exaustivo, em que não encontravam qualquer realização pessoal, reconhecimento ou prazer, e que se repetia da mesma maneira por anos a fio (Ibid., p. 66). 
A autora exemplificou essa questão da "frustração" através da fala de um operário do período: “Eu tinha uma ilusão tremenda de trabalhar numa fábrica de automóveis. Eu tinha aquela ilusão: trabalhar na Volkswagen. Eu entrei na Volks, passei dois anos e meio lá e para mim foi um martírio [...]" (Ibid., p. 87).

De acordo com Abramo, a tensão permanente e a sensação de "impotência" e de "submissão" existente no interior das empresas automobilísticas durante as décadas de 1960 e 1970 romperam não apenas com a "dignidade profissional" do trabalhador metalúrgico, mas também com a dimensão fundamental da sua própria existência como ser humano. Para ela: "A arbitrariedade e a impunidade da chefia [naquele período] expunham o trabalhador a situações perigosas e humilhantes, desrespeitando não apenas os direitos trabalhistas, mas até mesmo as regras mínimas da convivência humana" (Ibid., p. 111). A autora exemplificou essa questão através da fala de um trabalhador à época: "Sou trabalhador e, portanto, mereço ser tratado como gente" (Ibid., p. 47).

Além dos sentimentos de injustiça, perda e frustração, anteriormente citados, Abramo ressaltou outros elementos do cotidiano fabril que também reforçavam nos trabalhadores a sensação de "dignidade violentada": o fato de ter o dia todo cronometrado, dentro e fora da fábrica, sem tempo para o lazer ou a convivência familiar; gastar de duas a três horas por dia de transporte para ir e voltar da casa ao trabalho; trabalhar "que nem um burro de tropa"; não poder pescar aos domingos com os amigos por ter sido obrigado a fazer horas extras; ter o corpo massacrado pelo cansaço e refém dos acidentes de trabalho; ser obrigado a comer "comida que não se dá nem para cachorro"; estar exposto à violência policial nas ruas do bairro; não ter a possibilidade de expressar-se; não conseguir prover a família de uma refeição decente aos domingos; no caso das mulheres, ser constantemente assediada pelos chefes; não ter a qualificação 
profissional reconhecida e valorizada; ser humilhado por uma infinidade de "ordens sem réplica", além de diversos outros exemplos. Nas palavras de Abramo:

A relação dos trabalhadores com as chefias era especialmente tensa. Por parte delas, desrespeito, autoritarismo, prepotência. Por parte deles, impossibilidade de expressar-se, de fazer-se ouvir, de ter seus direitos e opiniões considerados. Tudo isso agravado pela sensação de estar sozinho, de não ter a quem recorrer e, portanto, de ser impotente para enfrentar a autoridade opressora (Ibid., p. 106).

Segundo Laís Abramo, foi contra toda essa situação de "dignidade violentada" que centenas de operários do ABC paulista em fins de 1970 cruzaram os braços e decidiram entrar em greve. A atividade grevista, portanto, foi uma forma encontrada pelos trabalhadores para resgatarem a sua dignidade. Em outras palavras: "A greve foi uma experiência de reparação de uma ferida profunda. [...] A greve representou a possibilidade, para os trabalhadores, de 'sentir-se novamente gente'" (Ibid., p. 269).

\section{Considerações Finais}

De acordo com o filósofo Michel Foucault, o Estado não é o único polo irradiador de poder numa sociedade. Para ele, a sociedade divide-se em uma relação de "micropoderes" que podem ser elaborados, percebidos e distribuídos de diversas maneiras. Ou seja, a seu ver, no interior de uma sociedade existem "[...] formas de exercício do poder diferentes do Estado, a ele articuladas de maneiras variadas e que são indispensáveis inclusive à sua sustentação e atuação eficaz" (FOUCAULT, 2006, p. XI). Nesta ótica de Foucault, as 
instituições de uma sociedade são também elaboradoras e distribuidoras de poder, isto é, de "micro-poderes". A universidade, por exemplo, não foge a essa regra. Examinada em seu conjunto e em profundidade, ela apresenta-se também dentro desse circuito de "micro-poderes".

A Academia, como corpo social, não é uma instituição homogênea. Dentro de uma mesma universidade, podem-se encontrar, por exemplo, intelectuais com orientações e posições não só diferentes como, às vezes, totalmente opostas, tanto em relação à questão metodológica e teórica, bem como à vinculação político-sociológico acerca do objeto em estudo.

A partir das leituras realizadas para a elaboração do presente artigo, essa percepção da academia como um corpo heterogêneo, um espaço de disputa ficou-nos bastante evidente. Os autores, na busca de legitimar o seu estudo e apresentar a sua visão como a mais completa e atual, procuraram apontar os erros e equívocos de seus pares, ao mesmo tempo em que desqualificando as outras linhas interpretativas apontando como limitadas e/ou reduzidas.

É importante destacar que essa disputa entre os cientistas sociais para legitimar a sua visão - demonstrando-a como a mais correta e, às vezes, a única possível sobre o fato - não foi exclusividade do objeto de estudo deste trabalho, isto é, não foi exclusividade das diferentes linhas interpretativas existentes para explicar a retomada do movimento operário no $\mathrm{ABC}$ paulista. Em todos os fatos históricos existem diversas linhas de interpretação. Na medida em que na História não há nada fixo, simples e estático, pois tudo é essencialmente aporético e complexo, as concepções e interpretações que se dão sobre ela são também múltiplas e pouco concludentes. A escrita da história segue, portanto, a dinâmica da própria História que é a complexidade, a mudança, a contradição e o movimento. 
Por fim, é importante destacar que, a nossa ver, na retomada da atividade grevista daquele período, diversos fatores e processos se entrecruzaram, conformando um período extremamente rico e intenso, que não cabe ser interpretada através de qualquer tipo de esquema teórico preestabelecido, pois cada dinâmica histórica é singular. Por isso, longe de procurar tecer um julgamento acerca das interpretações existente sobre o ressurgimento do movimento operário no país, qualificando em um juízo de valor entre melhor e pior, correto e a errado - até por que como nos ensinou Marc Bloch: "[...] ao historiador não cabe o julgamento dos fatos históricos, e sim sua compreensão" (BLOCH, 2001, p. 125) - o nosso objetivo foi tão somente compreender a produção das principais interpretações e narrativas existentes sobre a temática.

\section{Referências Bibliográficas}

ALMEIDA, Maria Hermínia Tavares de. O sindicato no Brasil: novos problemas, velhas estruturas. In: Debate e crítica, n. 6, julho, São Paulo: Hucitec, 1975.

. A autonomia sindical. In: Movimento, 18 jul. 1977.

. Desarrollo capitalista y acción sindical. In: Revista Mexicana de Sociología, n. 55, vol. II, México: 1978.

ABRAMO, Laís Wendel. O resgate da dignidade: greve metalúrgica e subjetividade operária. Campinas: Editora da UNICAMP; São Paulo: Imprensa Oficial, 1999.

ANTUNES, Ricardo. A rebeldia do trabalho: o confronto operário no abc paulista: as greves de 1978/1980. Campinas: Editora da UNICAMP, 1988.

BLOCH, Marc. Apologia da história, ou, O ofício de historiador. Rio de Janeiro: Jorge Zahar Ed., 2001.

FOUCAULT, Michel. Microfísica do poder. 22. ed. Rio de Janeiro: Ed. Graal, 2006. 
HUMPHREY, John. Fazendo o "milagre": controle capitalista e luta operária na indústria automobilística brasileira. Petrópolis: Vozes, 1982.

MARONI, Amnéris Angela. A estratégia da recusa: análise das greves de maio/78. São Paulo: Brasiliense, 1982.

MATTOS, Marcelo Badaró. O sindicalismo brasileiro após 1930. Rio de Janeiro: Jorge Zahar Ed., 2003.

MOISÉS, José Álvaro. Lições de liberdade e de opressão: os trabalhadores e a política. Rio de Janeiro: Paz e Terra, 1982.

RAINHO, Luís Flávio; BARGAS; Osvaldo Martines. As lutas operárias e sindicais dos metalúrgicos em São Bernardo (1977-1979). vol. 1. São Bernardo: Associação Beneficente e Cultural dos Metalúrgicos de São Bernardo do Campo e Diadema, 1983.

RODRIGUES, Iram Jácome. Sindicalismo e política: a trajetória da CUT. São Paulo: Scritta, 1997.

RODRIGUES, Leôncio Martins. Industrialização e atitudes operárias. São Paulo: Brasiliense, 1970.

SOUZA MARTINS, Heloisa Helena Teixeira de. O Estado e a burocratização do sindicato no Brasil. São Paulo: Editora HUCITEC, 1979.

WEIL, Simone. A condição operária e outros estudos sobre a opressão. Rio de Janeiro: Paz e Terra, 1979. 